\title{
Effect of restoration on zooplankton community in a permanent interdunal pond
}

\author{
Maria Anton-Pardo*, Carla Olmo, Juan M. Soria and Xavier Armengol \\ Department of Microbiology and Ecology, ICBIBE, University of Valencia, Spain
}

Received 23 November 2012; Accepted 28 March 2013

\begin{abstract}
Restoration projects in wetlands are becoming increasingly frequent to recover or to create new aquatic ecosystems, after the significant impact and high degradation they have undergone. In the present study, we focused on the changes in the zooplankton community in a permanent peridunal pond where a restoration was carried out in order to increase its surface as a main objective. For this purpose, the community was compared before and after the restoration (15 years before, the year after and between 3 and 6 years later). Significant changes in environmental variables were observed after pond restoration: chlorophyll $a$ concentration decreased and dissolved oxygen increased. Substantial modifications in the aquatic community were also observed, since species richness and diversity increased after restoration: a large number of new species appeared (84\%, mainly cladocerans), from external or internal sources. In addition, zooplankton community structure and composition changed from a low specific richness community copepod-dominated in density (mostly nauplii) before restoration, to another one with higher richness and different composition co-dominated in density by rotifers and nauplii, but with greater abundance of cladoceran species. All this suggests an important change in the ecological functioning of the pond, mainly produced by improvement in habitat heterogeneity and water quality after restoration.
\end{abstract}

Key words: Diversity / species richness / cladocerans / rotifers / trophic state

\section{Introduction}

Aquatic ecosystems from Mediterranean regions present high biodiversity (e.g., Myers et al., 2000), but they are especially vulnerable to some threats, mainly related to drainage and destruction, eutrophication, pollution, salinization or introduction of invasive species (Pearce and Crivelli, 1994; Grillas et al., 2004). Conservation policies are strictly necessary to preserve these ecosystems, but measures are frequently taken too late, and restoration projects must be carried out to recover damaged habitats and their biodiversity.

Although the main goal of ecological restoration is to enable the functioning of all the ecological processes in the restored system (Hobbs and Harris, 2001), this target is frequently forgotten. In many aquatic ecosystems, restoration projects mostly focus on eutrophication control by reducing the input of nutrients (Brouwer and Roelofs, 2001), or by the elimination or reduction of planktivorous or benthivorous fish (Jeppesen et al., 1990; Moss et al., 1996). The expected result of most of these changes is to

\footnotetext{
*Corresponding author: anparma@uv.es
}

avoid or reduce turbid states and to keep a permanent clear water phase in the aquatic ecosystems, to facilitate macrophyte development and improve water quality (Scheffer et al., 1993). The success of the restoration process is often based on comparisons with studies carried out prior to this one, reference sites or palaeolimnological studies (Drake and Naiman, 2000; Yan et al., 2004; Louette et al., 2009), which are not always available. For such evaluation aims and in order to assess the right functioning of the main ecological processes, several groups of organisms belonging to different trophic levels must be taken into consideration (Ruiz-Jaen and Aide, 2005). In this way, the community of planktonic invertebrates (which includes herbivorous, carnivorous and detritivorous species) plays a key role in the transfer of matter and energy in aquatic food webs, connecting primary producers and higher consumers. They can also be used as indicators for ecological processes, since their changes in abundance or diversity can be considered as a response to variations in water quality and can reflect modifications produced in lower and higher trophic levels (primary producers and predators, such as fish, respectively). Thus, they could be used to assess restoration 
measures (Louette et al., 2009; Azémar et al., 2010; Jeppesen et al., 2011; Mialet et al., 2011). Furthermore, zooplankton species from continental water bodies show good adaptations for dispersal and colonization of new habitats (Havel and Shurin, 2004). The success of this colonization mostly depends on these species dispersal capacity, influenced by regional factors (connectivity among water bodies, pond isolation or regional diversity; Frisch and Green, 2007; Badosa et al., 2010) and by local factors such as environmental variables, including habitat heterogeneity and the amount and viability of the sediment egg bank, which will hatch and grow under such potential environmental conditions (Brendonck and De Meester, 2003; Vandekerkhove et al., 2005).

Our study was carried out in a small permanent peridunal pond, which was restored in 2003 to increase its surface (from 300 to $4000 \mathrm{~m}^{2}$ ) and depth (from 1.5 to $2 \mathrm{~m}$ ) in order to improve its water quality and spatial heterogeneity, and to be able to shelter a permanent population of small endangered cyprinodontid fish species [Aphanius iberus (Valenciennes, 1846) and Valencia hispanica (Valenciennes, 1846)], which were previously in the pond but in low density due to the small size of the pond. Although sediment was probably disturbed during restoration, a viable and diverse egg bank was supposed to rest in the pond sediment, hence it would be expected that the zooplankton community present after restoration would be both the result of sediment egg bank hatching in the pond's new environmental conditions and the arrival of new species from other water bodies through dispersal vectors. In addition, submerged plants were introduced immediately after the restoration, possibly causing the introduction of some aquatic invertebrate species, but also producing a change in the habitat structure and the increase of heterogeneity.

The aim of this paper is to evaluate the changes on zooplankton community and limnological characteristics of this pond after its restoration in 2003. We hypothesise that this process modified several environmental variables in the water body, improving water quality (mainly a decrease in chlorophyll $a$ concentration and an increase in dissolved oxygen), and thus, zooplankton community turned into a more diverse community, with the presence of indicator species of these variations. For this purpose, the current zooplankton community and the environmental features (from Autumn 2006 to Summer 2009) were compared with a set of data obtained from a study performed 15 years before restoration (from February 1987 to January 1988; Soria García, 1988; Soria and Alfonso, 1993; Alfonso, 1996) and with data collected in 2004-2005, just after restoration.

\section{Methods}

\section{Study area}

The pond under study is located in the sandy stretch that separates the Mediterranean Sea and the Albufera de
Valencia (Spain), a freshwater lagoon (Fig. 1) in eastern Spain. It is part of a set of dune slacks, all of them filled with rainfall and groundwater and included in a protected area (Albufera Natural Park) but where, nevertheless, the anthropic pressure is very high. The lagoon is surrounded by agricultural areas and the Park is a recreational space with a high population density and visitors all year round. In the $1960 \mathrm{~s}-1970 \mathrm{~s}$, due to an urbanisation process in the area, most of these ponds were silted, losing all their habitat functions. However, in 1987, the area was declared a Natural Park and those urbanisation projects were stopped. Since the 1990s, several restoration projects have been undertaken to restore the coastal dune fields and to create new ponds in the silted old basins (more information can be found in Antón-Pardo and Armengol, 2010 and Ortells et al., 2012). However, the studied pond $\left(39^{\circ} 20^{\prime} 24.38^{\prime \prime} \mathrm{N} ; 0^{\circ} 18^{\prime} 34.92^{\prime \prime} \mathrm{W}\right)$ was not silted in that period and always maintained a water column more than $1 \mathrm{~m}$ deep at all times, but presented a high density of emergent vegetation and poor water quality (Soria and Alfonso, 1993). During summer 2003, the pond was restored by digging an adjacent basin, which was connected with the old one, making possible the arrival of zooplankton and fish from the old pond. The total surface was increased (from 300 to $4000 \mathrm{~m}^{2}$, Fig. 1) with the aim of using it as a reserve for the endemic fish species A. iberus and $V$. hispanica. Although it was not studied, before the restoration, the pond had a population of these small fish species, which remained in the restored pond. Aquatic plants were introduced (Chara hispida L., Potamogeton pectinatus L. and Zannichellia peltata Bertol.) and later the pond developed a dense belt of emergent vegetation of Phragmites australis (Cav.) Trin. Ex Steud. and Typha domingensis Pers. The introduced plants were from a fish farm of the Environmental Agency located in the area (El Palmar) and came from natural populations taken in water bodies of the Natural Park, hence the local gene pool was maintained.

\section{Sampling}

The samplings were carried out in three different periods: (i) before restoration (1987-1988), (ii) during the next hydrological cycle after restoration (2004-2005), and (iii) during the period between November 2006 and August 2009 (which comprised three hydrological cycles - from autumn, when the rainy period starts, to summer, when rain is almost null). Although the samplings were performed by different people in each period, similar equipment and methods were used throughout the time. In the study conducted prior to the restoration (1987-1988), a total of eight samples were taken bimonthly (Soria García, 1988; Soria and Alfonso, 1993; Alfonso, 1996). During 2004-2005 (just after restoration), four measures of environmental variables were taken in this period, but only two zooplankton samples were set up: one in September 2004 and another one in January 2005. And finally, between 2006 and 2009, samples were taken almost 


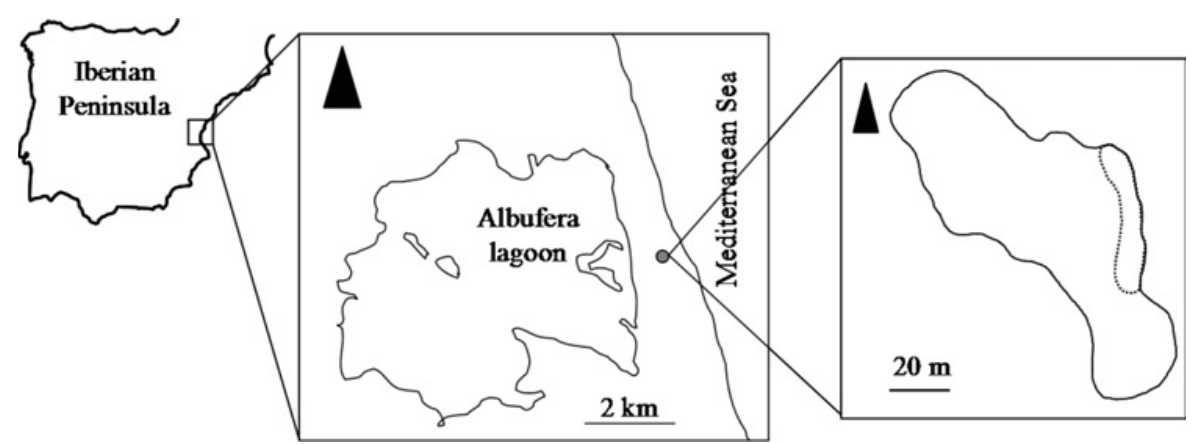

Fig. 1. Map of the study site. The grey dot shows the location of the studied pond on the map, and the dotted line shows the position of the old basin.

monthly (nine samples from autumn 2006 to summer 2007 and eight samples in the periods 2007-2008 and 2008-2009). In each sampling, conductivity, dissolved oxygen and $\mathrm{pH}$ were measured. The concentration of chlorophyll $a$ was also measured (except for the period 2004-2005), after extraction from Whatman glass fiber $\mathrm{GF} / \mathrm{F}$ filters using acetone $90 \%$, the concentration being determined by spectrophotometry and calculated following Jeffrey and Humphrey (1975). Zooplankton samples were taken by filtering a volume of water (from 6 to 15 liters) through a $35 \mu \mathrm{m}$ filter from different sites of the pond to include all found microhabitats (open water, littoral zone, and vegetated areas) in a single integrated sample. Organisms were fixed in 4\% formaldehyde and stored. Individuals were identified to species level when possible and counted in the laboratory using an inverted microscope.

\section{Data analyses}

A set of community parameters were calculated for the main zooplanktonic groups (rotifers, copepods, and cladocerans) in each period (before restoration, the year after restoration - 2004/2005 and for each hydrological cycle 3-6 years after restoration): organism density, species richness per visit (mean richness for each period), cumulative species richness (total number of species found in each period), and the Shannon-Wiener Diversity Index. These values were compared using the non-parametric test of Kruskal-Wallis, and when this analysis was significant, the pairwise comparisons were performed employing the non-parametric post hoc Mann-Whitney test. Statistic analyses were made using the software PAST (Hammer et al., 2008).

\section{Results}

The comparison between the environmental variables (Table 1) showed that conductivity did not present significant changes for each hydrological cycle during all the study periods. However, the Kruskal-Wallis analysis showed that dissolved oxygen concentration significantly differed along the study period $(P<0.01)$.
The Mann-Whitney test results revealed that concentration was lower before restoration: differences were significant between the 1987 and 1988 cycle and the last three cycles $(P<0.05$ for $2006-2007 ; P<0.01$ for the last 2 years). The period 2007-2008 had the highest mean oxygen concentration, which was significantly higher than in 2004-2005, 2006-2007 $(P<0.05)$ and 1987-1988 $(P<0.01)$. Averaged chlorophyll $a$ concentration decreased after restoration from $27.7 \mu \mathrm{g} . \mathrm{L}^{-1}$ in $1987-1988$ to a minimum of $2.2 \mu \mathrm{g} . \mathrm{L}^{-1}$ in the period 2006-2009 $(P<0.01)$. Significant differences were also observed for the mean $\mathrm{pH}$ values, with lower mean values before restoration (1987-1988) than for the last few years (2006-2009; $P<0.05)$.

Zooplankton species richness increased gradually after restoration (Fig. 2a). Before restoration, 16 species were found (14 rotifers, one copepod and one cladoceran). Immediately after restoration (the two samples from 2004 to 2005), a total of 26 zooplankton species were counted (23 rotifers, one copepod and two cladocerans). During the period 2006-2009, 78 species were identified: 54 species in the first hydrological cycle, 48 in 2007-2008 and 55 species in the last cycle. From 2006 to 2009, rotifers were the richest group (60 species), followed by cladocerans (13 species) and copepods (five species). As sampling frequency differed during each period, species richness per visit was compared (Fig. 2b), and differences among periods were also found. For rotifers, species richness was significantly lower before restoration (1987-1988) than immediately after it $(2004-2005 ; P<0.05)$, and also lower than for the last 3 years $(P<0.01)$. For copepods, differences were significant between the first sampling period in 1987-1988, when only one copepod species per visit was found, and for the cycles 2006-2007 and 2008-2009, when two copepod species per visit appeared $(P<0.05)$. Regarding cladocerans, the only species observed before restoration was Daphnia magna. In 2004-2005, two species were found, but without any significant differences if compared with the first cycle. However, the differences observed among cladoceran richness per visit before restoration and in the last 3 years were significant $(P<0.01)$ : between 2006 and 2009 the number of cladoceran species per visit ranged between 2.4 and 3.8. This value was also significantly higher than the 

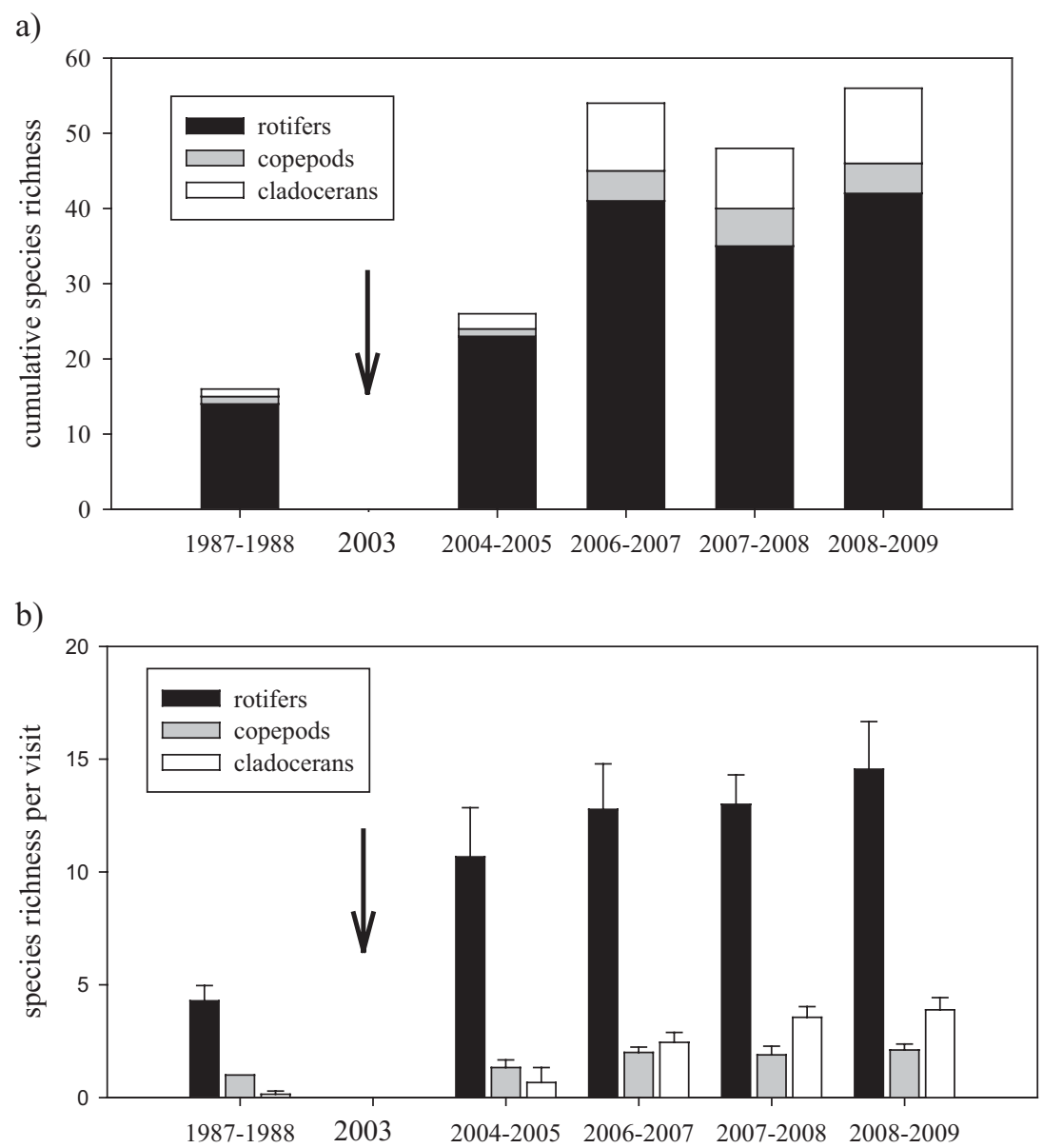

Fig. 2. (a) Cumulative richness for the main zooplankton groups (rotifers, copepods and cladocerans) in the different periods studied. (b) Mean species richness (and standard error) for the main zooplankton groups (rotifers, copepods and cladocerans) in different years. The arrow shows the time when the pond was restored.

Table 1. Average values and standard errors of the environmental variables measured and the Shannon-Wiener diversity index $\left(\mathrm{H}^{\prime}\right)$ in different hydrological cycles. The grey background represents the period before the restoration. $(-)$, no data.

\begin{tabular}{|c|c|c|c|c|c|c|}
\hline & $\bar{N}$ & Conductivity $\left(\mu \mathrm{S} . \mathrm{cm}^{-1}\right)$ & Dissolved oxygen (mg.L ${ }^{-1}$ ) & Chlorophyll $a\left(\mu \mathrm{g} . \mathrm{L}^{-1}\right)$ & $\mathrm{pH}$ & $\mathrm{H}^{\prime}$ \\
\hline $1987-1988$ & 8 & $1613.0 \pm 191.9$ & $4.7 \pm 1.6$ & $27.69 \pm 4.07$ & $7.7 \pm 0.3$ & $0.5 \pm 0.1$ \\
\hline 2004-2005 & 4 & $2053.5 \pm 384.5$ & $7.7 \pm 3.8$ & $(-)$ & $(-)$ & $0.7 \pm 0.3$ \\
\hline 2006-2007 & 9 & $1786.3 \pm 48.1$ & $8.8 \pm 2.9$ & $2.20 \pm 0.66$ & $8.7 \pm 0.1$ & $2.1 \pm 0$ \\
\hline 2007-2008 & 8 & $1950.5 \pm 101.8$ & $12.0 \pm 4.2$ & $4.1 \pm 1.2$ & $8.9 \pm 0.1$ & $2.3 \pm 0.3$ \\
\hline 2008-2009 & 8 & $1888.8 \pm 105.5$ & $9.9 \pm 3.5$ & $2.17 \pm 0.97$ & $8.5 \pm 0.1$ & $2.3 \pm 0.3$ \\
\hline
\end{tabular}

cladoceran richness reported in 2004-2005 $(P<0.05)$. Species richness was also compared using only the coincident sampling months (considering only the months of November, January, April, May and July for 1987-1988 and 2006-2009). Even so, the results revealed that species richness rose significantly after pond enlargement $(P<0.05)$.

The Shannon-Wiener Diversity Index increased after restoration (Table 1), with values above 2 in the last 3 years, if compared with 0.5 before restoration $(P<0.01)$ and with 0.7 in the cycle $2004-2005(P<0.05)$.

The comparison of the mean density for each cycle (Fig. 3) indicates that rotifers were the only group with no significant differences in abundance among periods, with a maximum mean value of 911.4 ind. $\mathrm{L}^{-1}$ in 2008-2009 and a minimum mean value of 62.6 ind. $\mathrm{L}^{-1}$ in $2006-2007$. Copepods displayed higher density before restoration, with more than 1500 ind. $\mathrm{L}^{-1}$; mainly due to the high density of nauplii and copepodites. This value significantly differed for copepod density in 2004-2005 $(P<0.05)$ and in 2006-2009 $(P<0.01)$. Cladocerans exhibited the opposite tendency, with greater abundance between 2006 and 2009 (14.1 ind. $\mathrm{L}^{-1}$ ) when compared with their density before restoration $\left(0.04\right.$ ind.L $\left.{ }^{-1} ; P<0.01\right)$ and immediately after restoration $\left(1.0\right.$ ind. $\left.\mathrm{L}^{-1} ; P<0.05\right)$.

Changes in the composition and relative abundance of the dominant rotifers and crustaceans noticed for each period (Fig. 4) were also remarkable. Before restoration, 


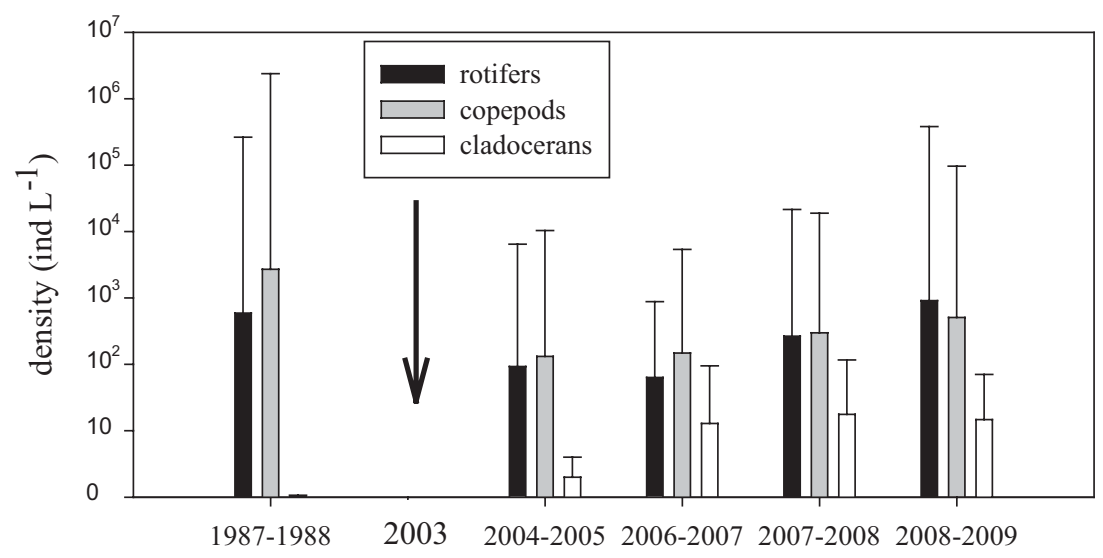

Fig. 3. Mean density and standard error of the main zooplanktonic groups for each year in the study period. The arrow shows the time when the pond was restored.
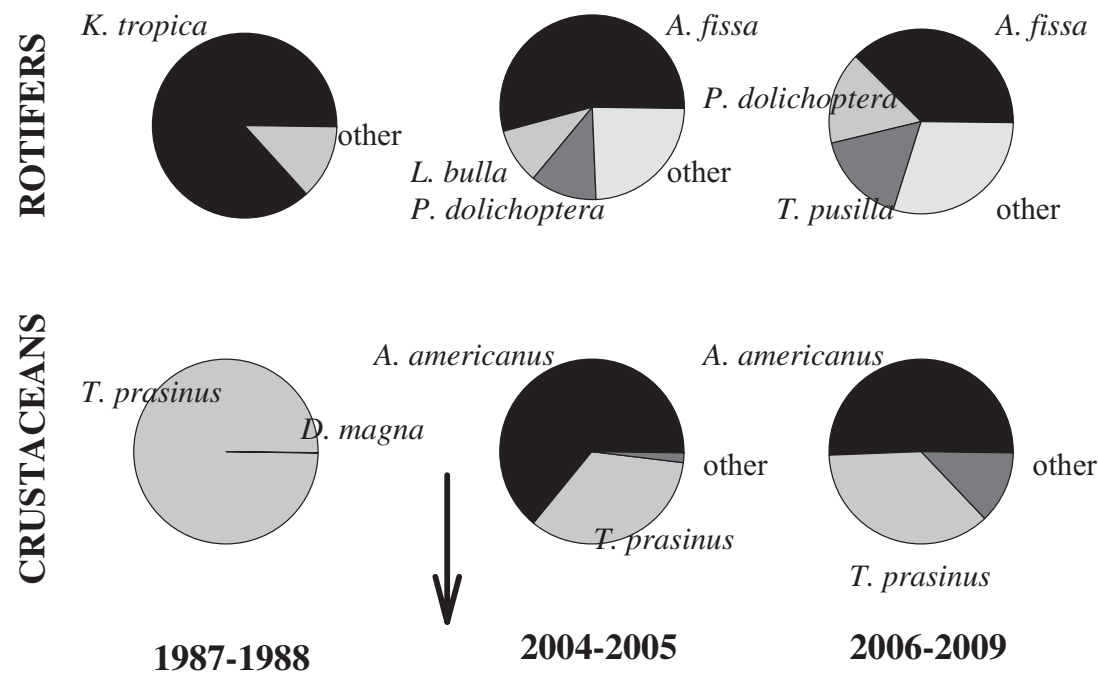

Fig. 4. Relative abundance (percentage) of rotifer (upper circle) and crustacean species (lower circle). The arrow shows the time when the pond was restored.

the community was dominated in density by the rotifer Keratella tropica (with a percentage of $86.7 \%$ ) and the juvenile stages of the copepod Tropocyclops prasinus $(99.9 \%)$. After enlarging the pond surface, the dominant species was, for rotifers, Anuraeopsis fissa (above 50\%) and for crustaceans, nauplii of Acanthocyclops americanus $(63.8 \%)$. These dominant species did not undergo any major changes in the last 3 years studied, but their relative abundance was modified: $A$. fissa and A. americanus decreased to $38 \%$ and $50 \%$, respectively. On the other hand, the main rotifer species which increased their density were Trichocerca pusilla and Polyarthra dolichoptera.

Almost the total number of species found (85\%) were new species - mainly rotifers - which appeared in the pond after restoration (Table 2; Appendix 1). The density of one of them, A. fissa, increased from average 68.3 ind. $^{-1}$ immediately after restoration to 274.3 ind. $\mathrm{L}^{-1}$ in the last 3 years, being at this moment the dominant species. The increase observed for the cladoceran species after restoration (12 species) is remarkable, while the only species found before restoration was D. magna, one of the few species found in all the periods sampled, together with five rotifer species (the taxa Bdelloidea was not included since different species could be present). Some of these rotifers presented high densities, such as $K$. tropica (dominant in 1987-1988 with an average density of 1744 ind. $\mathrm{L}^{-1}$ ) or $P$. dolichoptera (with an average density of 116.4 ind. $^{-1}$ in the last 3 years). Recovered species considered were those present before restoration, but they were not found immediately after restoration and they reappeared in the last 3 years. Only two rotifers, B. angularis and B. urceolaris (recorded as disappeared species), were found in 1987-1988, but not in the periods following restoration.

\section{Discussion}

This work highlights the important changes that took place in the zooplankton community, as well as in the limnological characteristics after restoration of a small pond by enlarging its surface, depth and introducing macrophytes. The data reveal that the zooplankton 
Table 2. Number of species found during the study period classified according to its presence or absence in each cycle before and after restoration. Disappeared: present before the restoration (1987-88) and absent after; recovered: present before the restoration, absent just after restoration (2004-2005), and present in the last three periods studied (2006-2009); always present: species present after and before restoration; new: new species found after restoration.

\begin{tabular}{lcccc}
\hline & Disappeared & Recovered & Always present & New \\
\hline Rotifers & 2 & 3 & 6 & 1 \\
Copepods & & & 1 & 4 \\
Cladocerans & 2 & 3 & 8 & 12 \\
TOTAL & 2 & & 73 \\
\hline
\end{tabular}

community responded to this change in a short time (after only 1 year post-restoration) as specific richness and diversity increased. In addition, community composition also changed if compared with the community found some years before restoration. These changes are in agreement with other studies where fast colonization by zooplankton, vegetation or macroinvertebrates has been reported (Williams et al., 2008; Badosa et al., 2010).

An improvement of the trophic state was one of the main changes registered by the comparison of environmental variables, suggested because the mean chlorophyll $a$ concentration decreased. Although chlorophyll $a$ is one of the main indicators for the trophic state, this statement should be taken with caution in shallow lakes, which can be dominated by macrophytes (Canfield et al., 1983), and, on the other hand, the absence of comparable values of nutrient concentrations before and after restoration cannot confirm this statement. Nevertheless, other factors such as the increase of dissolved oxygen and $\mathrm{pH}$ after restoration, related to production/decomposition processes are also supporting this fact. The lower oxygen concentration observed before restoration was probably due to its high consumption by the large amount of organic matter (high decomposition rate) and humic compounds (Scheffer, 2004), which were accumulated in the sediment before restoration, when emergent vegetation was very abundant (Soria, personal observation). The rise of $\mathrm{pH}$ values after restoration also supports this statement, since this variable increases if respiration rates and humic compounds decrease and it can also reflect variations in primary production (by macrophytes and by phytoplankton; Wetzel, 2001).

Substantial enhancement in species richness and the appearance of many new species after restoration may be related to different factors: (a) arrival of resting stages from external sources through dispersal; (b) re-colonization from internal sources (sediment egg bank); and (c) due to the new environmental conditions, increased species abundance, which were present before restoration, but in low densities that are hard to detect in samplings (Keller and Yan, 1998). This pond is located in an area with high regional diversity with many water bodies, including rice fields and a large lagoon (Albufera) and hence, these surrounding ponds can act as important zooplankton reservoirs (Antón-Pardo and Armengol, 2010; Olmo et al., 2012). The arrival of new species from external sources can take place through several dispersal vectors.
In our study area, the wind (Caceres and Soluk, 2002; Vanschoenwinkel et al., 2008b) and water birds (Figuerola and Green, 2002), frequently observed in the enlarged pond (individuals of Anas platyrhynchos, Gallinula chloropus or Bubulcus ibis), could be considered important dispersal vectors. However, dispersal associated with human activities and through other terrestrial animals (Vanschoenwinkel et al., 2008a; Waterkeyn et al., 2010) was important as well, since the presence of people and other animals (dogs and wild boars) is common in this area. In addition, during the restoration project, aquatic vegetation was introduced; thus, some zooplankters might have been introduced unintentionally in this way. Although fish and plants were not included in the present study, their effect cannot be neglected as they are keystone species in aquatic habitats (Scheffer, 2004) that can modify, in an important way, the food web and the structure of the aquatic community. Fish were present in the pond throughout the study period (before and after restoration) and their population increased, particularly A. iberus was considered very abundant in the periodic controls conducted in the last period using minnow traps (unpublished information from the technicians of the Environmental Agency).

On the other hand, the work carried out to enlarge the pond area can contribute to digging up still viable buried resting stages, which may hatch under the pond's new environmental conditions. Some studies conducted in invertebrates and vegetation have suggested the importance of this viable present egg bank to facilitate colonization after pond restoration (Brouwer and Roelofs, 2001; Brady et al., 2002; Jenkins and Boulton, 2007).

In addition, increased habitat heterogeneity (horizontal and vertical) may create new ecological niches and could favour the occurrence and adaptation of a large number of species (Crosetti and Margaritora, 1987; Keller and Yan, 1998; Antón-Pardo and Armengol, 2010). Before the restoration (1987-1988), the open water microhabitat dominated the pond, whereas after the introduction and development of macrophytes, a percentage of vegetation cover of more than $70 \%$ was observed in most of the samplings. Moreover, the species were different: mainly helophytes in the littoral area of the pond in 1987-1988, and a bed of charophytes after the restoration process. Submerged vegetation, natural and introduced during the restoration, is one of the main variables that contribute to habitat heterogeneity, but it is 
also an important source of oxygen, a shelter against predation and a food source for zooplankton (Scheffer, 2004; Rennie and Jackson, 2005), which can explain an increase in the number of rotifer species, as found in other systems (Duggan, 2001; Kuczynska-Kippen, 2001).

The change noticed in the dominant zooplankton species also highlights the modifications observed in the community. Before restoration, the dominant species were those adapted to eutrophic conditions, such as K. tropica or nauplii of T. prasinus (Dussart, 1969; Koste, 1978). At this time, a unique cladoceran species, D. magna, a cosmopolitan species that tolerates a wide range of environmental conditions (Alonso, 1996), appeared with low abundance in a single sample during winter (February), a period when fish activity is low. After restoration, some indicators of eutrophic conditions such as $A$. fissa were present, but they did not reach high densities or biomass (considering its small size). In addition, the number as well as density of cladoceran species rose strongly, pointing out the improvement of water quality, as this group is more sensitive to habitat features (Jeppesen et al., 2011).

Most studies that have focused on ecological restoration stress the importance of carrying out assessment studies to confirm the success of these processes (Hobbs and Harris, 2001; Ruiz-Jaen and Aide, 2005). In our case, studies prior to habitat degradation were not available, but zooplankton community can be used as an indicator of water quality after the restoration process (Jenkins and Boulton, 2007). Thus, we can conclude that the enlarged size, the increase in habitat heterogeneity and complexity and the other consequent changes occurring in this pond, have improved habitat and water quality in a short period of time. This statement is supported by the increase in oxygen concentration and $\mathrm{pH}$ and the decrease in chlorophyll $a$ concentration. As a consequence, changes in community composition were produced; zooplankton richness and diversity increased, favouring the appearance of a high number of species, mainly cladocerans, which indicate an improvement of water quality.

Acknowledgements. This study has been carried out within the framework of the Spanish Government project (CGL200803760/BOS) and the Generalitat Valenciana project (GVPRE/ 2008/408). MAP and CO are predoctoral fellows from the Spanish Government (AP2005-3298 and BES-2009-018518). The authors thank the staff at the Oficina Técnica La Devesa l'Albufera, Piscifactoría El Palmar and Parc Natural de l'Albufera de València; Juan Rueda, who took the samples of 2004-2005; Teresa Alfonso and William Colom who participated in the study prior to the restoration; and Patricia Raad, who corrected the language.

\section{References}

Alfonso M.T., 1996. Estudio de las comunidades zooplanctónicas de los ecosistemas acuáticos del Parque Natural de la
Albufera de Valencia. Dissertation, University of Valencia, Valencia, $310 \mathrm{p}$.

Alonso M., 1996. Crustacea. Branchiopoda. Fauna Ibérica, Vol. 7, Museo Nacional de Ciencias Naturales, CSIC, Madrid, $486 \mathrm{p}$.

Antón-Pardo M. and Armengol X., 2010. Zooplankton community from restored peridunal ponds in the Mediterranean region (L'Albufera Natural Park, Valencia, Spain). Limnetica, 29, 133-144.

Azémar F., Maris T., Mialet B., Segers H., Van Damme S., Meire P. and Tackx M., 2010. Rotifers in the Schelde estuary (Belgium): a test of taxonomic relevance. J. Plankton Res., 32, 981-997.

Badosa A., Frisch D., Arechederra A., Serrano L. and Green A.J., 2010. Recovery of zooplankton diversity in a restored Mediterranean temporary marsh in Doñana National Park (SW Spain). Hydrobiologia, 654, 67-82.

Brady V.J., Cardinale B.J., Gathman J.P. and Burton T.M., 2002. Does facilitation of faunal recruitment benefit ecosystem restoration? An experimental sudy of invertebrate assemblages in wetland mesocosms. Restor. Ecol., 10, 617-626.

Brendonck L. and De Meester L., 2003. Egg banks in freshwater zooplankton: evolutionary and ecological archives in the sediment. Hydrobiologia, 491, 65-84.

Brouwer E. and Roelofs J.G.M., 2001. Degraded softwater lakes: possibilities for restoration. Restor. Ecol., 9, 155-166.

Caceres C.E. and Soluk D.A., 2002. Blowing in the wind: a field test to overland dispersal and colonization by aquatic invertebrates. Oecologia, 131, 402-408.

Canfield D.E. Jr., Langeland K.A., Maceina M.J., Haller W.T., Shireman J.V. and. Jones J.R., 1983. Trophic state classification of lakes with aquatic macrophytes. Can. J. Fish. Aquat. Sci., 40, 1713-1718.

Crosetti D. and Margaritora F.G., 1987. Distribution and life cycles of cladocerans in temporary pools fromCentral Italy. Freshwat. Biol., 18, 165-175.

Drake D.C. and Naiman R.J., 2000. An evaluation of restoration efforts in fishless lakes stocked with exotic trout. Conserv. Biol., 14, 1807-1820.

Duggan I.C., 2001. The ecology of periphytic rotifers. Hydrobiologia, 446/447, 139-148.

Dussart B., 1969. Les copépodes des eaux continentales d'Europe occidentale, Tome II : Cyclopoïdes et Biologie, Boubee \& Cie, Paris, 292 p.

Figuerola J. and Green A.J., 2002. Dispersal of aquatic organisms by waterbirds: a review of past research and priorities for future studies. Freshwat. Biol., 47, 483-494.

Frisch D. and Green A.J., 2007. Copepods come in first: rapid colonization of new temporary ponds. Fundam. Appl. Limnol., 168, 289-297.

Grillas P., Gauthier P., Yavercovski N. and Perennou C., 2004. Mediterranean Temporary Pools, Vol. 1, Issues relating to conservation, functioning and management, Tour du Valat, France, $119 \mathrm{p}$.

Hammer O., Harper D.A.T. and Ryan P.D., 2008. PASTPalaentological Statistics, ver. 1.81, Sweden, $88 \mathrm{p}$.

Havel J.E. and Shurin J.B., 2004. Mechanisms, effects, and scales of dispersal in freshwater zooplankton. Limnol. Oceanogr., 49, 1229-1238.

Hobbs R.J. and Harris J.A., 2001. Restoration ecology: repairing the Earth's ecosystems in the new millennium. Restor. Ecol., 9, 239-246. 
Jeffrey E. and Humphrey G.F., 1975. New spectrophotometric equations for determining chlorophylla $a, b, c 1$ and $c 2$ in higher plants, algae and natural phytoplankton. Biochem. Physiol. Pflanzen, 167, 91-194.

Jenkins K.M. and Boulton A.J., 2007. Detecting impacts and setting restoration targets in arid-zone rivers: aquatic microinvertebrates responses to reduced floodplain inundation. J. Appl. Ecol., 44, 823-832.

Jeppesen E., Jensen J.P., Kristensen P., Sondergaard M., Mortensen E., Sortkaer O. and Olrik K., 1990. Fish manipulation as a lake restoration tool in shallow, eutrophic, temperate lakes 2: threshold levels, long-term stability and conclusions. Hydrobiologia, 200/201, 219-227.

Jeppesen E., Noges P., Davidson T.A., Haberman J., Noges T., Blank K., Laridsen T.L., Sondergaard M., Sayer C., Laugaste R., Johansson L.S., Bjerring R. and Amsink S.L., 2011. Zooplankton as indicators in lakes: a scientific-based plea for including zooplankton in the ecological quality assessment of lakes according to the European Water Framework Directive (WFD). Hydrobiologia, 676, 279-297.

Keller W. and Yan N.D., 1998. Biological recovery from lake acidification: zooplankton communities as a model of patterns and processes. Restor. Ecol., 6, 364-375.

Koste W., 1978. Rotatoria. Die Räderiere Mitteleuropas, Monogonta, Gebrüder Borntraeger, Berlin, 673 p.

Kuczynska-Kippen N., 2001. Diurnal vertical distribution of rotifers (Rotifera) in the Chara zone of Budzyńskie Lake, Poland. Hydrobiologia, 446, 195-201.

Louette G., Declerk S., Vandekerkhove J. and De Meester L., 2009. Evaluation of restoration measures in a shallow lake through a comparison of present day zooplankton communities with historical samples. Restor. Ecol., 17, 629-640.

Mialet B., Gouzou J., Azémar F., Maris T., Sossou C., Toumi N., Van Damme S., Meire P. and Tackx M., 2011. Response of zooplankton to improving water quality in the Scheldt estuary (Belgium). Estuar. Coastal Shelf Sci., 93, 47-57.

Moss B., Stasfield J., Irvine K., Perrow M. and Phillips G., 1996. Progressive restoration of a shallow lake: a 12-year experiment in isolation, sediment removal and biomanipulation. J. Appl. Ecol., 33, 71-86.

Myers N., Mittermeier R.A., Mittermeier C.G., da Fonseca G.A.B. and Kent J., 2000. Biodiversity hotspots for consevation priorities. Nature, 403, 853-858.

Olmo C., Armengol X. and Ortells R., 2012. Re-establishment of zooplankton communities in temporary ponds after autumn flooding: does restoration age matter? Limnologica, 42, 310-319.

Ortells R., Olmo C. and Armengol X., 2012. Colonization in action: genetic characteristics of Daphnia magna Strauss
(Crustacea, Anomopoda) in two recently restored ponds. Hydrobiologia, 689, 37-49.

Pearce F. and Crivelli A.J., 1994. Characteristics of Mediterranean Wetlands, Tour du Valat, France, $90 \mathrm{p}$.

Rennie M.D. and Jackson L.J., 2005. The influence of habitat complexity on littoral invertebrate distributions: patterns differ in shallow prairie lakes with and without fish. Can. J. Fish. Aquat. Sci., 62, 2088-2099.

Ruiz-Jaen M.C. and Aide T.M., 2005. Restoration success: how is it being measured? Restor. Ecol., 13, 569-577.

Scheffer M., 2004. Ecology of Shallow Lakes, Kluwer Academic Publishers, The Netherlands, $357 \mathrm{p}$.

Scheffer M., Hosper S.H., Meijer M.L., Moss B. and Jeppesen E., 1993. Alternative equilibria in shallow lakes. Trends Ecol. Evol., 8, 275-279.

Soria J.M. and Alfonso M.T., 1993. Relations between physicochemical and biological characteristics in some coastal intradune ponds near Valencia (Spain). Verh. Int. Ver. Theor. Angew. Limnol., 25, 1009-1013.

Soria García J.M., 1988. Estudio limnológico de las malladas de la Devesa de la Albufera, Technical report, Ayuntamiento de Valencia, Oficina Técnica Devesa y Albufera, Valencia, 95 p.

Vandekerkhove J., Declerck S., Brendonck L., Conde Porcuna J.M., Jeppesen E. and De Meester L., 2005. Hatching of cladoceran resting stages: temperature and photoperiod. Freshwat. Biol., 50, 96-104.

Vanschoenwinkel B., Waterkeyn A., Vandecaetsbeek T., Pineau O., Grillas P. and Brendock L., 2008a. Dispersal of freshwater invertebrates by large terrestrial mammals: a case study with wild boar (Sus scrofa) in Mediterranean wetlands. Freshwat. Biol., 53, 2264-2273.

Vanschoenwinkel B., Gielen S., Seaman M. and Brendonck L., 2008b. Anyway the wind blows - frequent wind dispersal drives species sorting in ephemeral aquatic communities. Oikos, 117, 125-134.

Waterkeyn A., Vanschoenwinkel B., Elsen S., Anton-Pardo M., Grillas P. and Brendock L., 2010. Unintentional dispersal of aquatic invertebrates via footwear and motor vehicles in a Mediterranean wetland area. Aquat. Conserv.: Mar. Freshwat. Ecosyst., 20, 580-587.

Wetzel R.G., 2001. Limnology. Lake and River Ecosystems, Third edn, Elsevier Academic Press, USA, 1006 p.

Williams P., Whitfield M. and Biggs J., 2008. How can we make new ponds biodiverse? A case study monitored over 7 years. Hydrobiologia, 597, 137-148.

Yan N.D., Girard R., Heneberry J.H., Keller W.B., Gunn J.M. and Dillon P.J., 2004. Recovery of copepod, but not cladoceran, zooplankton from severe and chronic effects of multiple stressors. Ecol. Lett., 7, 452-460. 


\section{Appendix}

Appendix 1. List of the species found during the study period classified according to its presence or absence in each cycle.

\begin{tabular}{|c|c|c|c|c|}
\hline & Disappeared & Recovered & Always present & $\mathrm{New}$ \\
\hline Brachionus angularis Gosse, 1851 & $\mathrm{X}$ & & & \\
\hline Brachionus urceolaris Müller, 1773 & $\mathrm{X}$ & & & \\
\hline Synchaeta oblonga Ehrenberg, 1832 & & $\mathrm{X}$ & & \\
\hline Synchaeta pectinata Ehrenberg, 1832 & & $\mathrm{X}$ & & \\
\hline Testudinella patina (Hermann, 1783) & & $\mathrm{X}$ & & \\
\hline Tropocyclops prasinus (Fischer) 1860 & & $\mathrm{X}$ & & \\
\hline Bdelloidea & & & $X$ & \\
\hline Keratella tropica (Apstein, 1907) & & & $\mathrm{X}$ & \\
\hline Lecane bulla (Gosse, 1851) & & & $\mathrm{X}$ & \\
\hline Lepadella patella (Müller, 1786) & & & $X$ & \\
\hline Lophocharis salpina (Ehrenberg, 1834) & & & $\mathrm{X}$ & \\
\hline Polyarthra dolichoptera Idelson, 1925 & & & $\mathrm{X}$ & \\
\hline Daphnia magna Straus, 1820 & & & $X$ & \\
\hline
\end{tabular}

Anuraeopsis fissa (Gosse, 1851)

Brachionus plicatilis Müller, 1786

Brachionus ibericus Ciros-Pérez et al., 2001

Brachionus quadridentatus brevispinus Ehrenberg, 1832

Brachionus rotundiformis Tschugunoff, 1921

Cephalodella catellina (Müller, 1786)

Cephalodella cf. intuta Myers, 1924

Cephalodella gibba (Ehrenberg, 1832)

Cephalodella sp.

Colurella adriatica Ehrenberg, 1831

Colurella obtusa (Gosse, 1886)

Colurella uncinata (Müller, 1773)

Collotheca sp.

Cupelopagis vorax (Leidy, 1857)

Eosphora najas Ehrenberg, 1830

Euchlanis cf. meneta (Myers, 1930)

Hexarthra fennica (Levander, 1892)

Hexarthra oxyuris (Sernov, 1903)

Lecane decipiens (Murray, 1913)

Lecane aculeata (Jakubski, 1912)

Lecane closterocerca (Schmarda, 1859)

Lecane furcata (Murray, 1913)

Lecane hamata (Stokes, 1896)

Lecane inopinata Harring and Myers, 1926

Lecane nana (Murray, 1913)

Lecane obtusa (Murray, 1913)

Lecane papuana (Murray, 1913)

Lecane punctata (Murray, 1913)

Lecane pyriformis (Daday, 1905)

Lecane quadridentata (Ehrenberg, 1832)

Lecane luna (Müller, 1776)

Lecane curvicornis (Murray, 1913)

Lecane flexilis (Gosse, 1889)

Lecane hornemanni (Ehrenberg, 1834)

Lecane lunaris (Ehrenberg, 1832)

Lepadella acuminata (Ehrenberg, 1834)

Lepadella ovalis (Müller, 1786)

Lepadella rhomboides (Gosse, 1886)

Lepadella triptera (Ehrenberg, 1830)

Lindia torulosa (Dujardin, 1841)

Mytilina ventralis (Ehrenberg, 1832)

Notholca squamula (Müller, 1786)

Notholca acuminata (Ehrenberg, 1832)

Platyias quadricornis (Ehrenberg, 1832)

cf. Proales

cf. Ptygura 
(Appendix 1). (Contd)

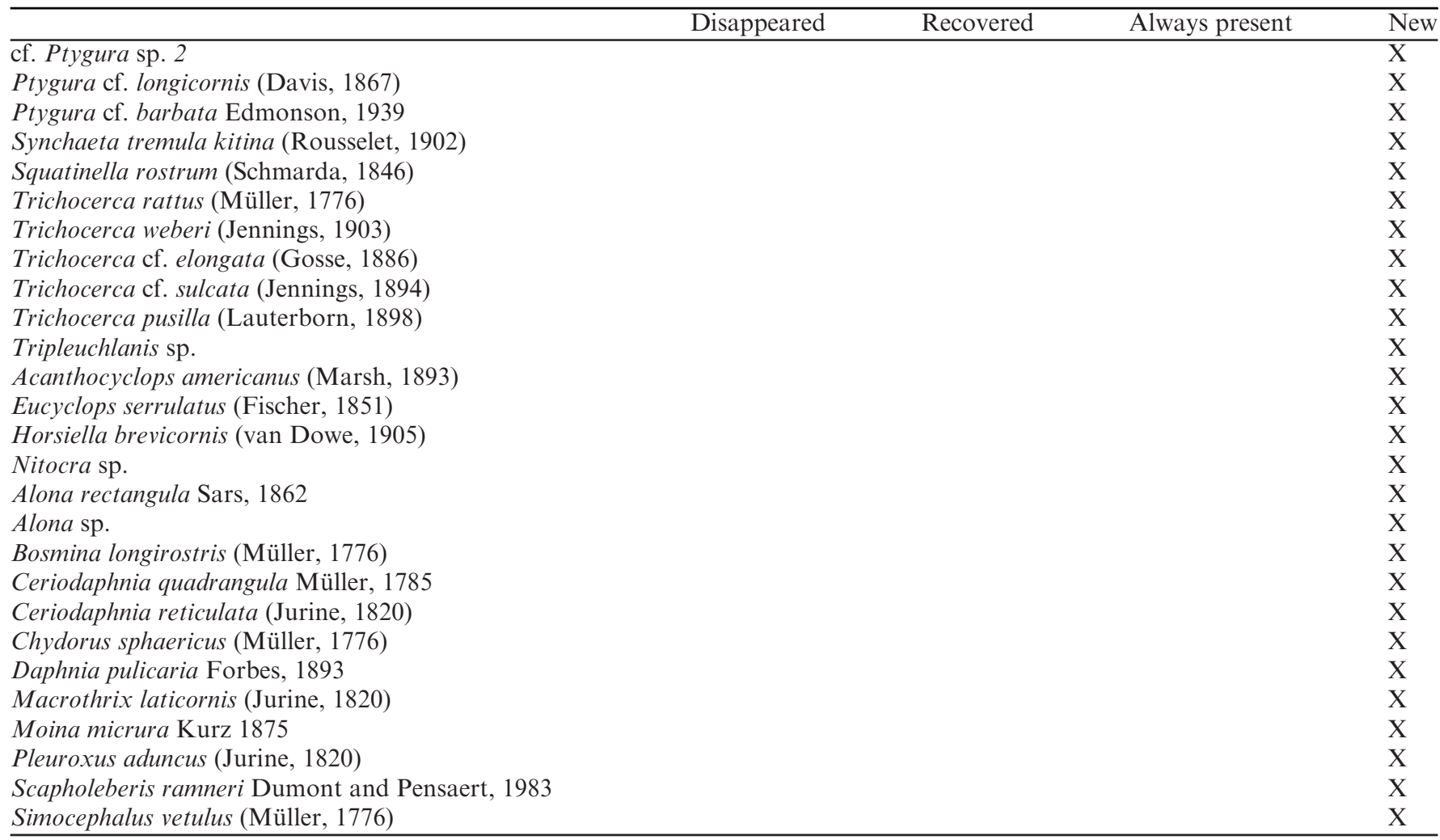

